\title{
Two Cases of Electrode Kinking in Cochlear Implantation
}

\author{
Saehee Lim, Hyunjung Kim, Jae Hyung Kim, and Gi Jung Im \\ Department of Otolaryngology-Head and Neck Surgery, College of Medicine, Korea University, Seoul, Korea
}

\section{인공와우 이식술 시 전극 꼬임 2예}

임세희 · 김현정 · 김재형 · 임기정

고려대학교 의과대학 이비인후과학교실

\author{
Received May 31, 2016 \\ Revised August 1,2016 \\ Accepted August 12, 2016 \\ Address for correspondence \\ Gi Jung Im, MD \\ Department of Otolaryngology- \\ Head and Neck Surgery, \\ College of Medicine, \\ Korea University, \\ 73 Inchon-ro, Seongbuk-gu, \\ Seoul 02841, Korea \\ Tel $+82-2-920-5345$ \\ Fax $+82-2-925-5233$ \\ E-mail earkorea@gmail.com
}

Less traumatic electrode insertion along the basal turn of cochlea is essential to cochlear implantation. However, immoderate attempts to insert the electrode beyond the point of resistance can result in electrode kinking within the basal turn of cochlea. Electrode kinking tends to occur 1) in the use of contour or hugging type of electrode, 2) in the cochlear ossification or fibrosis, and 3) in wrong angle insertion in the approach of round window membrane or cochleostomy near the round window. Intra-operative radiologic evaluation and intra-operative measurement of the neural response telemetry or auditory nerve response telemetry during cochlear implantation is essential to check the status and proper insertion of electrode. Recently, we experienced two cases of electrode kinking in cochlear implantation and discovered that both patients showed abnormal impedances and crumpled electrode in X-ray. Based on these cases, we suggest routine impedance and radiologic measurement during the cochlear implantation. Korean J Otorhinolaryngol-Head Neck Surg 2017;60(10):527-30

Key Words Cochlea Cochlear implantation · Electrode $\cdot$ Ossificaition.

\section{서 론}

인공와우 이식술은 양측의 고도 감각신경성 난청을 가진 환 자들의 청력재활치료에 필수적인 방법으로, 2012년 기준 전 세계적으로 324200건이 시술되었다.1) 인공와우 이식술 중 기 술적으로 중요한 과제중의 하나는 가능한 모든 전극을 와우 의 기저부 회전(basal turn)에 부드럽게 손상 없이 삽입하는 것이다. 이를 간과하면 와우에 손상을 주거나 저항으로 인하 여 전극 자체가 망가질 수 있으며 재수술을 필요로 할 수 있다. 이처럼 전극을 잘못되게 삽입하는 비율은 $0.17 \sim 2.12 \%$ 로 보 고된 바가 있다.2)

이 같은 와우 내 전극을 이식하는 과정에서 전극의 위치나 전극 이식 시 발생할 수 있는 손상은 환자의 언어수행능력에

This is an Open Access article distributed under the terms of the Creative Commons Attribution Non-Commercial License (http://creativecommons.org/licenses/by-nc/4.0) which permits unrestricted non-commercial use, distribution, and reproduction in any medium, provided the original work is properly cited.
영향을 미치기 때문에 이를 확인하고 수술에 반영시키기 위 한 노력이 필요하다. 대표적으로 시행되었던 연구방법 중 하 나인 측두골 조직병리검사를 통한 확인은 사후에 이루어진 다는 단점과 손상 후 재형성(remodeling)을 거친 이후라는 단 점이 있다. ${ }^{3)}$ 또한 수술 후 고해상도 측두골 단층촬영(temporal bone computed tomography)을 시행하는 방법은 모든 사람 에게 시행하기 어려우며, 수술 중 와우 내 손상은 파악할 수 없는 단점이 있다. ${ }^{4)}$ 따라서 실제적으로는 술 중 단순와우촬 영검사(cochlear view)를 확인하는 방법이 많이 쓰인다.

Mason 등 ${ }^{5}$ 은 1995 년 인공와우 이식 수술 중 전기청성뇌간 반응(electrical evoked auditory brainstem response) 등의 검사 방법을 소개하며 이의 유용성을 언급한 바 있는데, 장 비의 작동 여부와 청신경 경로를 통한 신경 반응을 즉시 확 인할 수 있으며, 유소아 환자의 술 후 $\mathrm{T}, \mathrm{C}$ level 결정 시 적절 하게 활용할 수 있고 술 후 결과의 기초자료가 될 수 있다는 것이다. 또한 Mason ${ }^{6}$ 은 다른 연구에서 신경반응원격측정검 
사(neural response telemetry, NRT)의 술 중 검사의 장점을 언급하였고 NRT 검사 결과가 아동의 술 후 조율에 도움이 된다고 지적한 바 있다.

전극 꼬임(electrode kinking)이란 인공와우의 전극이 정원 창(round window) 또는 와우 개창술(cochleostomy)로 삽입 되어 와우 내로 진행하는 과정 중 저항점에 의하여 꺾이고 구 부러지며 와우 내에서 제기능을 하지 못하는 경우 등을 총칭 한다. 이에 저자들은 수술 중 신경반응원격측정검사 및 방사 선학적인 검사를 통하여 전극 꼬임 여부를 파악하고 이를 전 극 재삽입으로 교정한 2 개의 인공와우 전극 꼬임 증례들을 치험하였기에 이를 보고하는 바이다. 또한, 전극 꼬임이 나타

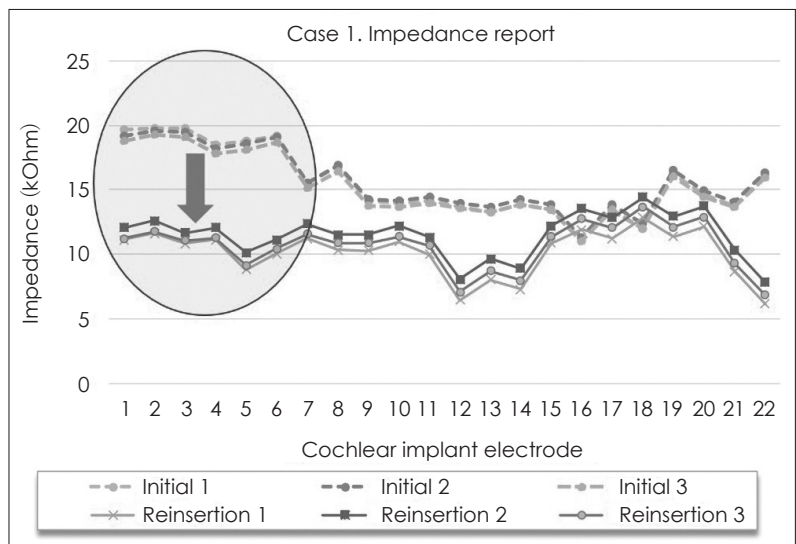

Fig. 1. Neural response telemetry in Case 1. The graph illustrates initial impedance values (dotted lines) versus re-inserted electrode's impedance values (full lines). Electrode impedance was increased especially in channels from 1 to 6 (opened) at 1st insertion. After checking electrode kinking using intra-operative cochlear view, kinked electrode was removed, and re-insertion was successfully done. After re-insertion, impedance became normal, and intra-operative measurements of the neural response were within normal range.
난 사례들을 통하여 전극 꼬임이 발생할 수 있는 다양한 상 황에 대한 분류법을 제시해 보고자 한다.

\section{증 례}

\section{증 례 1}

70세 여자 환자가 우측은 출생 시부터, 좌측은 4개월 전 돌 발성 난청으로 인하여 생긴 양측 청력저하를 주소로 내원하 였다. 순음청력검사 상 양측 전농 소견이었으며, 청성뇌간유발 반응검사(Auditory Brainstem Response Threshold Test) 검사 및 청성지속반응검사(Auditory Steady State Response Test) 상 양측 귀에서 반응을 보이지 않았다.

환자의 수술 전 측두골 컴퓨터단층촬영검사 상에서는 양 측 와우 기저부 회전 기저막이 두터워진 소견을 보였으나, 두 드러진 와우 골화 소견은 관찰되지 않았다. 이에 전농의 기간 이 짧은 좌측에 대하여 Nucleus CI24RE(Cochlear Limited, Lane Cove, Australia) 모델을 사용한 인공와우 이식술을 계 획하였다.

본 환자에 대하여 수술 중 신경반응원격측정검사와 단순 와우촬영검사를 확인하였으며, 첫 전극(electrode) 삽입 후 3 차례 시행한 신경반응 원격측정검사에서 환자의 전극 중 낮 은 값(distal portion to apex area of cochlea)으로 갈수록 임피던스가 증가하는 경향을 보였다(Fig. 1, dotted line). 또 한, 수술 중 단순와우촬영검사에서 삽입된 전극부위를 확대 하여, electrode 끝부분이 비정상적으로 말려 있는 모습을 확 인하였다(Fig. 2A).

이에 전극 꼬임이 나타난 것으로 판단하고 전극을 빼낸 뒤 와우 개창술(cochleostomy)을 아랫부분으로 연장시켜 넓힌

Fig. 2. Kinking of cochlear electrode in Case 1. The tip of cochlear implant electrode was kinked in the basal turn of left cochlea. The coil is folded (A) once the electrode kinking occurs, and can be straightened after reinsertion (B). Intra-operative radiologic evaluation is essential to check the status of electrode and proper insertion of cochlear implant electrode.
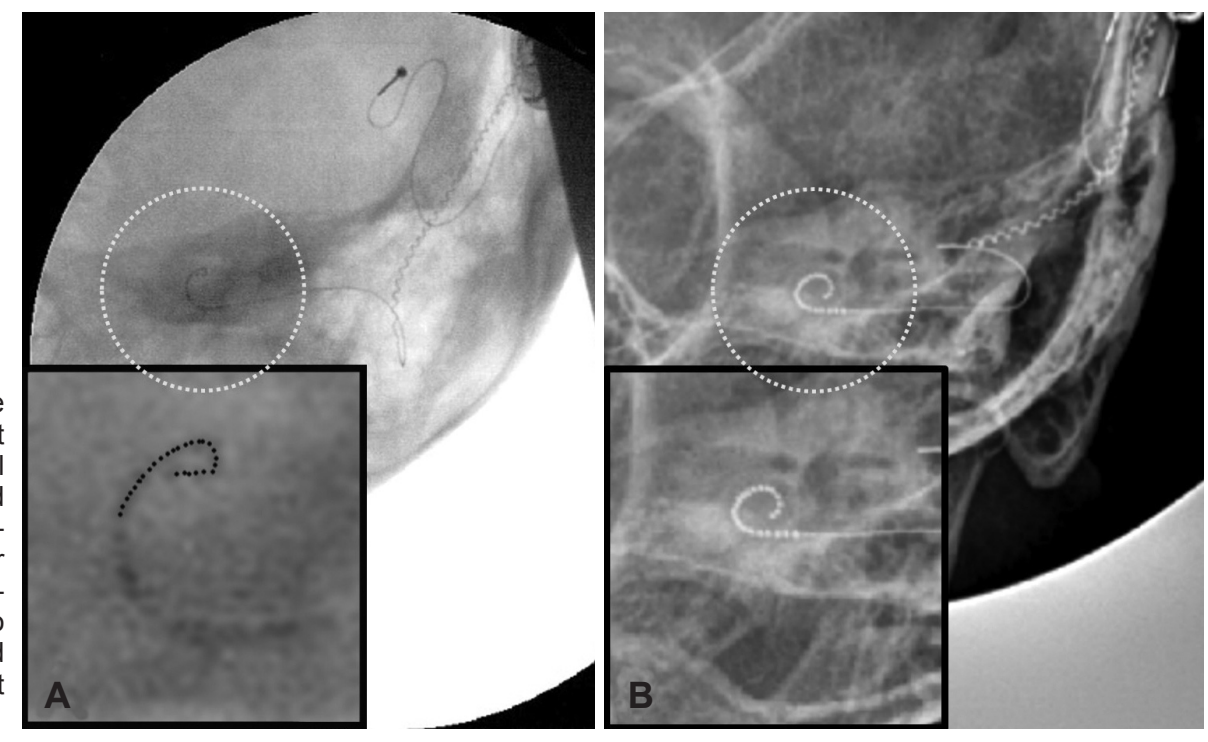
뒤 전극을 재삽입하였고, 두 번째 시도에서 3차례 시행한 신 경반응원격측정검사 값이 정상화된 것(Fig. 1, full line)과 단순와우촬영검사에서 전극이 끝까지 펴진 채로 정상 삽입된 것을 확인한 후 수술을 종료하였다(Fig. 2B). 환자는 수술 전 말 지각 능력 검사 결과, categories for auditory performance 0점, Open-set 단어 검사결과 auditory only(AO) 상황에서 듣 기 확인이 $0 \%$ 였으나 수술 1년 후 검사 결과 CAP 7점, Openset 단어 검사 결과 $\mathrm{AO}$ 상황 1음절 단어 듣기는 $84 \%, 2$ 음절 단어 듣기는 $88 \%$, 문장 듣기는 $90 \%$ 의 수준으로 향상된 결 과를 보였다.

\section{증 례 2}

특이 과거력 없는 43세 남자 환자가 양측 청력저하를 주소 로 내원하였다. 외래에서 시행한 순음청력검사 및 청성뇌간반 응검사에서 양측 전농 소견을 보였던 분으로 측두골 컴퓨터 단층촬영검사에서 좌측 골화성 미로가 확인되어 Clarion Helix(Advanced Bionics, Valencia, CA, USA)의 모델을 사

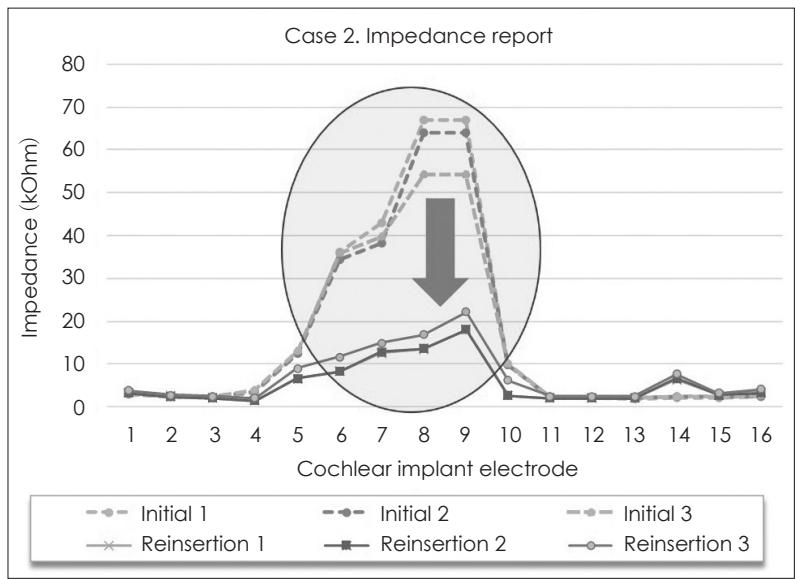

Fig. 3. Neural response imaging in Case 2. The graph illustrates initial impedance values (dotted lines) versus re-inserted electrode's impedance values (full lines). High values at 6-9 electrodes are seen in the Case 2 impedance report, indicating open and nonfunctioning electrodes (dotted lines). The impedance values became normalized (full lines) after reinsertion of the electrode.
용한 우측 인공와우 이식술을 계획하였다. 술자는 후고실 개방 술 시행 후 와우 개창술을 통한 접근법을 이용하여 전극 삽 입을 시도하였다. 환자의 인공와우 이식술 중 3 차례 시행한 신경반응원격측정검사에서 모두 중간 전극(mid electrode) 의 임피던스 값이 높게 나타났고(Fig. 3, dotted line), 이어 시 행한 단순와우촬영검사에서 역시 전극 꼬임이 발생한 모양 을 확인할 수 있었다(Fig. 4A). 이에 전극을 빼내어 재삽입을 시도하였으며 이어 시행한 수술 중 방사선 검사에서 전극이 깨끗하게 펴진 채로 삽입된 것(Fig. 4B)과 신경반응원격측정 검사 상에서 임피던스 값이 정상화된 것을 3 차례 확인 후 수 술을 종료하였다(Fig. 3, full line).

\section{고 찰}

인공와우 이식술 시 전극 꼬임은 굴곡진 타입(contour type) 또는 감싸는 타입(hugging type)의 전극을 사용할 때, 전극이 정원창이나 주변 와우 개창술을 통하여 잘못된 각도로 삽입
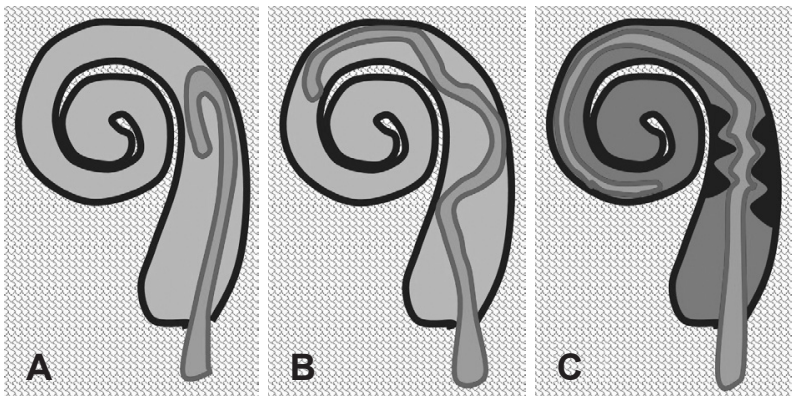

Fig. 5. The picture above shows 3 types of electrode kinking that can be distinguished by different points of resistance where the electrode kinking occurs. As the electrode enters the cochlea, resistance from the opening (basal portion) causes the apex of the electrode to dysfunction (A). As the electrode enters deeply from the cochleostomy, resistance counteracts against the movement, creating kinking in the mid-portion of the electrode (B). Furthermore, either whole or partial portion of the electrode is damaged due to resistance from the passage through the narrow portion of ossification (C). All 3 cases can be revealed by both intra-operative Neural response telemetry and cochlear view.
Fig. 4. Kinking of cochlear electrode in Case 2. The middle area of cochlear implant electrode was kinked in the basal turn of right cochlea. This intra-operation cochlear view image presents crumpling in the mid-portion of the electrode $(A)$, resulting in a star-shape. After re-insertion, the electrode is straightened, and is in round shape $(B)$.
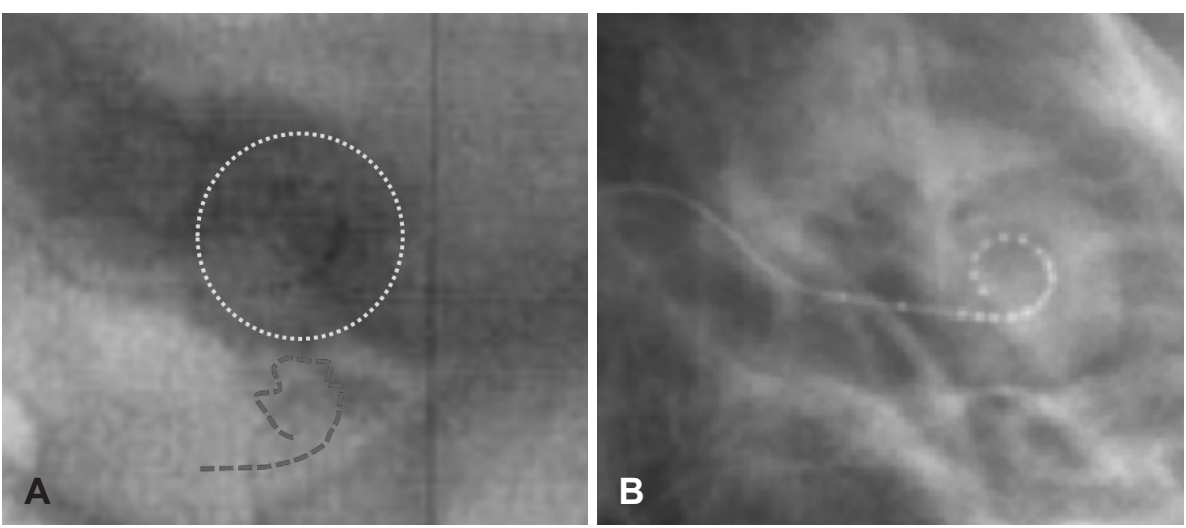
될 때 나타날 수 있다. 주로 와우의 골화나 섬유화가 있는 환 자들에게서 일어나는 것으로 알려져 있으며, ${ }^{7,8)}$ 측두골 컴퓨 터단층촬영검사에서 와우 골화, 섬유화 소견이 뚜렷하지 않 는 환자에서도 전극이 와우의 기저회전에 들어가면서 일부 좁아지거나 섬유화된 저항점으로 인하여 전극 꼬임이 발생 할 수 있다. 따라서 전극 꼬임의 발생 가능성을 높이는 와우 의 골화 유무를 수술 전 측두골 컴퓨터단층촬영검사를 통하 여 확인하는 것이 필요하며, 수술 중 전극 꼬임이 의심되는 경우에는 와우 개창술을 보다 정확한 위치에, 넓게 시행하여 전극을 삽입하거나 정원창을 통하여 삽입할 때 전극의 삽입 각도를 와우의 기저회전 방향을 따라서 삽입하려는 노력을 통하여 전극 꼬임을 예방할 수 있겠다.

전극 꼬임의 발생형태를 분류해보면, 증례 1과 같이 전극 이 들어가는 입구부터 저항을 받게 되었을 때는 전극의 앞 부분이 기능장애를 일으키게 된다(Fig. 5A). 또한, 와우 중간 의 골화 또는 저항점이 존재하여 전극의 완전 삽입이 불가한 상황에서 수술자가 전극을 모두 넣으려고 과도한 삽입을 시 도하는 경우, 증례 2 와 같이 전극이 중앙부에서 휘어지거나 구겨져서 전극 꼬임이 일어날 수 있다(Fig. 5B). 마지막으로, 전극이 와우 골화 등으로 생긴 좁은 부분을 지나가면서 저항 및 손상을 받으면 해당부분의 일부 전극이 망가지거나, 이미 지나간 전체 전극이 손상을 받을 수 있다(Fig. $5 \mathrm{C}$ ). 이와 같은 경우, 부분 와우 골화 시에는 정점 와우 개창술(apical cochleostomy)이, 전체 와우 골화 시에는 전정계를 통한 전극 삽입 이나 와우의 드릴 아웃(drill-out) 기법이 시도되고 있다. ${ }^{9-12)}$

이처럼 전극 꼬임의 형태를 발생 지점 및 꼬인 모양에 따라 3 가지 형태로 구분할 수 있으며 이는 신경반응원격측정검사 및 단순와우촬영검사에서 서로 다른 양상으로 나타날 수 있 겠다(Fig. 5), 본 증례에서도 인공와우 이식술 중 전극꼬임이 발생하였을 때 수술 중 신경반응원격측정검사에서 전극 꼬 임이 나타난 부분의 임피던스 값이 증가하고, 단순와우촬영 검사에서는 전극의 끝이나 일부가 구부러지거나(증례 1), 전 극이 완전삽입되지 못하고 별 모양으로 휘어지거나 구부러지 는 모양(증례 2)을 볼 수 있다.

이와 관련하여 타 연구에서는 전극이 상반고리 관으로 진 입하였으나 신경반응원격측정검사 결과가 거의 정상에 가까 웠던 증례 2예를 보고하면서, 수술 중 신경반응원격측정검사 와 방사선학적 평가는 서로 다른 역할을 할 수 있는데, 신경 반응원격측정검사가 전극의 온전성을 확인할 수 있고 전극 과 와우의 인터페이스를 평가할 수 있다면 방사선학적 평가 는 전극진입이 올바르게 되었는지 여부 및 실제 진입된 위치 를 확인하는 데에 도움이 될 수 있기 때문에, 두 가지의 검사
가 모두 필요함을 주장한 바 있다. ${ }^{13)}$ 또한 다른 저자들은 인공 와우 이식술 후 어지럼을 호소한 환자를 통하여, 수술 중 신경 반응원격측정검사가 적정한 수준을 보였지만 수술 종료 후 시행한 전산화단층촬영검사에서 전극이 수평반고리관 부위 로 진입된 것을 확인했던 경험을 보고하였는데, ${ }^{2)}$ 수술을 종 료하기 전 단순와우촬영검사까지 병행하였더라면 수술 중 전극의 잘못된 삽입방향을 확인하여 재삽입할 기회가 있었을 것으로 생각한다.

이에 본 저자들은, 수술 중 신경반응원격측정검사를 통하 여 전극의 임피던스 값과 청각신경반응을 측정하고, 단순와 우촬영검사를 함께 시행하여 전극의 올바른 와우 내 삽입을 확인하는 것이 매우 중요하며, 모든 인공와우 이식술에서 두 검사를 항상 시행하여야 한다고 주장하는 바이다.

\section{REFERENCES}

1) National Institute on Deafness and Other Communication Disorders (NIDCD). Cochlear Implants [cited 2016 May 3]. Available from: URL: http://www.nidcd.nih.gov/health/cochlear-implants.

2) Tange RA, Grolman W, Maat A. Intracochlear misdirected implantation of a cochlear implant. Acta Otolaryngol 2006;126(6):650-2.

3) Nadol JB Jr, Shiao JY, Burgess BJ, Ketten DR, Eddington DK, Gantz $\mathrm{BJ}$, et al. Histopathology of cochlear implants in humans. Ann Otol Rhinol Laryngol 2001;110(9):883-91.

4) Ketten DR, Skinner MW, Wang G, Vannier MW, Gates GA, Neely JG. In vivo measures of cochlear length and insertion depth of nucleus cochlear implant electrode arrays. Ann Otol Rhinol Laryngol Suppl 1998:175:1-16.

5) Mason SM, Garnham CW, Sheppard S, O’Donoghue GM, Gibbin KP. An intraoperative test protocol for objective assessment of the nucleus 22-channel cochlear implant. Nottingham Paediatric Cochlear Implant Programme. Adv Otorhinolaryngol 1995;50:38-44.

6) Mason S. Electrophysiologic and objective monitoring of the cochlear implant during surgery: implementation, audit and outcomes. Int J Audiol 2004;43 Suppl 1:S33-8.

7) Kameswaran M, Kumar RS, Murali S, Natarajan K, Krishnan V. Cochlear implantation in ossified cochlea-Merf experience. Indian J Otolaryngol Head Neck Surg 2005;57(4):327-9.

8) Green JD Jr, Marion MS, Hinojosa R. Labyrinthitis ossificans: histopathologic consideration for cochlear implantation. Otolaryngol Head Neck Surg 1991;104(3):320-6.

9) Balkany T, Gantz BJ, Steenerson RL, Cohen NL. Systematic approach to electrode insertion in the ossified cochlea. Otolaryngol Head Neck Surg 1996;114(1):4-11.

10) Senn P, Rostetter C, Arnold A, Kompis M, Vischer M, Häusler R, et al. Retrograde cochlear implantation in postmeningitic basal turn ossification. Laryngoscope 2012;122(9):2043-50.

11) Hohman MH, Backous DD. Techniques for cochlear implant electrode placement in the ossified cochlea. Oper Tech Otolaryngol-Head Neck Surg 2010;21(4):239-42.

12) Smullen JL, Balkany TJ. Implantation of the ossified cochlea. Oper Tech Otolaryngol Head Neck Surg 2005;16:117-20.

13) Viccaro M, Covelli E, De Seta E, Balsamo G, Filipo R. The importance of intra-operative imaging during cochlear implant surgery. Cochlear Implants Int 2009;10(4):198-202. 